(C) Group of authors, 2019

UDC 616-001.8-089

DOI - https://doi.org/10.14300/mnnc.2019.14118

ISSN - 2073-8137

\title{
CLINICAL AND NEUROPHYSIOLOGICAL FEATURES OF DIFFERENT IN STRUCTURE COMBINED TRAUMAS
}

\author{
Nazarova E. O. ${ }^{1}$, Karpov S. M. ${ }^{1}$, Apaguni A. E. ${ }^{1,2}$, Karpov A. S. ${ }^{1}$, Krokhmal' S. V. ${ }^{1}$ \\ ${ }^{1}$ Stavropol State Medical University, Russian Federation \\ 2 City clinical hospital of emergency medical care, Stavropol, Russian Federation
}

\section{КАИНИКО-НЕЙРОФИЗИОАОГИЧЕСКИЕ ОСОБЕННОСТИ СОЧЕТАННЫХ ТРАВМ}

\author{
Е. О. Назарова ', С. М. Карпов ', А. Э. Апагуни 1, 2, А. С. Карпов ', С. В. Крохмаль ${ }^{1}$ \\ ${ }^{1}$ Ставропольский госуАарственный меАицинский университет, Российская ФеАерация \\ 2 ГороАская больница скорой МеАицинской помощи, Ставрополь, \\ Российская ФеАерация
}

The study included 102 patients with a combination of brain concussion (BC) and skeletal and thoracic injuries. The control group, 32 patients with isolated BC, was included. Neuropsychological testing and neurophysiological studies of EEG, HRV and P300 were performed. Depressive and asthenic disorders were revealed in the vast majority of patients with combined trauma. Cognitive decline was more marked in patients with thoracic combined trauma. The asymmetry of cortical activity of the brain prevailed in patients with the combined pelvicinjury. And vegetative regulation was characterized by the prevalence of parasympathetic influence against the background of increased sympathetic reactivity throughout the acute period. Thus, due to the difference in the mechanisms of «mutual burdening», the structures of the clinical course and specific neurophysiological characteristics differ in their structure.

Keywords: combined trauma, vegetative regulation, mutual burdening syndrome

В исследование были включены 102 пациента с сочетанием сотрясения головного мозга и скелетных и торакальных повреждений. В контрольную группу вошли 32 пациента с изолированным сотрясением головного мозга. Проводилось нейропсихологическое тестирование и нейрофизиологические исследования: ЭЭГ, ВРС и РЗ00. У подавляющего большинства пациентов с сочетанной травмой (СТ) выявлены депрессивные и астенические нарушения. Когнитивное снижение в большей степени было отмечено у пострадавших с торакальной СТ. Асимметрия корковой активности головного мозга преобладала у пациентов с СТ таза. Вегетативная регуляция характеризовалась превалированием парасимпатического влияния на фоне повышенной симпатической реактивности на протяжении всего острого периода. Таким образом, разные по структуре СТ с учетом разности механизмов «взаимного отягощения» имеют особенности клинического течения и специфические нейрофизиологические характеристики.

Ключевые слова: сочетанная травма, вегетативная регуляция, синдром взаимного отягощения

For citation: Nazarova E. O., Karpov S. M., Apaguni A. E., Karpov A. S., Krokhmal' S. V. CLINICAL AND NEUROPHYSIOLOGICAL FEATURES OF DIFFERENT IN STRUCTURE COMBINED TRAUMAS. Medical News of North Caucasus. 2019;14(3):486-489. DOI - https://doi.org/10.14300/mnnc.2019.14118

Для цитирования: Назарова Е. О., Карпов С. М., Апагуни А. Э., Карпов А. С., Крохмаль С. В. КЛИНИКО-НЕЙРОФИЗИОЛОГИЧЕСКИЕ ОСОБЕННОСТИ СОЧЕТАННЫХ ТРАВМ. Медицинский вестник Северного Кавказа. 2019;14(3):486489. DOI - https://doi.org/10.14300/mnnc.2019.14118

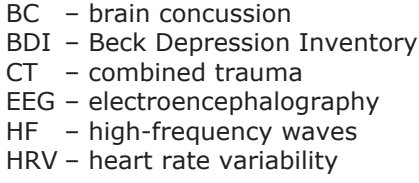

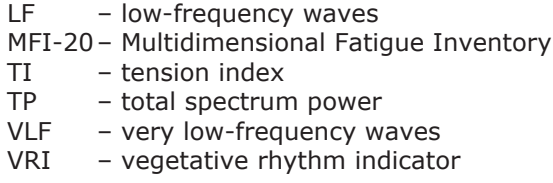

0 ne of the global problems of the XXI century is the growth of traumatism. The combined traumas (CT) take a special place in structure of traumatism; their features of pathogenesis depend on the structure of injuries included in their composition [1]. Mild neurotrauma in the combination is found in almost $80 \%$ of all cases of injuries, and its negative role in the course of the acute and recovery periods increases due to the syndrome of mutual burdening and overlap $[2,3$, 4].

The study aimed to evaluate the indicators of cognitive and psychoemotional disorders and the features of autonomic regulation in patients with CT. 
Material and Methods. The clinical research was carried out based on the combined trauma department of hospital. The study included 134 people, 102 of them received treatment in the department in the period 2013-2017. Among them, women were 36 (35.3\%) and men $-66(64.7 \%)$. The average age of patients was $30.2 \pm 8.2$ years. A combination of injuries was considered in 3 groups: group 1 consisted of 37 (36.3\%) patients with a combination of brain concussion (BC) with fractures of the lower extremities; group 2 - 32 (31.4\%) patients with $\mathrm{BC}$ and chest injury and group $3-33(32.3 \%)$ patients with $B C$ and pelvic fractures. The control group consisted of 32 patients with isolated $B C$.

Clinical and neurologic examinations were carried out, and psycho-emotional state was defined with the help of the asthenia questionnaire Multidimensional Fatigue Inventory (MFI-20), Spielberg-Khanin scale of anxiety, Beck Depression Inventory(BDI). Cognitive functions were also evaluated with the Montreal Scale (Montreal, Quebec, Canada). Neurophysiological techniques concluded EEG, the definition of cognitive potential P300, and heart rate variability (HRV).

Statistical data processing was done using of application package program Statistica 10 (Stat Soft, USA). The level of statistical significance was recorded at the level of error probability 0.05 .

Results and Discussion. A high number of complaints, which the patients with combined trauma have, can be connected in cephalic, asthenovegetative and cognitive impairment syndrome.

Neurological examination revealed the next patterns: $82(80.4 \%)$ patients with combined trauma have horizontal nystagmus with extreme leads. 51 (50.0\%) patients have positive symptoms of oral automatism, in particular, the symptoms of sucking in Marinescu - Radovich. 37 (36.3\%) studying patients have disturbances of oculomotor FMN in the form of convergence weakness, reduction of the radius of eyeball movements, $12(11.7 \%)$ patients have asymmetry of nasolabial folds, $23(22.6 \%)$ patients have manifestations of the pseudobulbar syndrome. There were similar changes in the control group: in 24 (75.0\%)patients were the nystagmus was noticed, in $9(28.1 \%)$ - there were oculomotor disorders, in $3(9.4 \%)$ have central nerve disorder and violation by the bulbar group of central origin in $6(18.8 \%)$ patients. To realize a complete assessment of the motor and sensitive spheres, coordinator violations weren't possible due to the presence of a forced position, skeletal traction, or immobilization of the extremities with plaster brackets.

All examined patients had autonomic dysfunction syndrome. In $92.5 \%$ of all examinations (124 patients) we could note the signs of imbalance of the autonomic nervous system in the form of pronounced distal hyperhidrosis in $83.8 \%$ (31 patients) in the group 1; in $78.1 \%$ (25 cases) in the group 2, in $87.9 \%$ (29 patients) in the group 3 and in $75.0 \%$ (24 cases) in the control group. Red spilled resistant dermographism was specific for $79.1 \%$ (106 patients) of all cases. It was maintained even during the second examination after three weeks of treatment of patients in the hospital department.

One of the purposes of studying was the definition of the psychoemotional state of patients with combined trauma. Analysis of data on the level of depression shows that $95 \%$ of patients with injuries are disposed to depressions. The patients with skeletal and pelvic combined traumas have the highest level of depression $(p=0.0090)$.

For the definition of asthenia, the scale MFI-20 was used. In the overwhelming majority of researching patients and from control groups, there were manifes- tations of asthenia in the «total asthenia», «decreased activity" and "reduced motivation" subscales. However, statistically significant differences in the scales of the questionnaire, depending on the structure of the trauma weren't found in this study. In other words, asthenia is an integrative manifestation of the course of an acute period of neurotrauma, both isolated and combined $[5,6]$.

There is a cognitive deficit in the acute period. All groups with differences in structure injuries are different according to Mocha-test's results (Table 1): respondents scored the smallest number of points from the group with chest CT, but in all these studied groups, including the control group, the total number of points didn't reach 26 points $(p=0.0090)$.

Table 1

The comparison of the «Moca-test's»values in patients with different combined traumas structures (medium and mean-square deviations)

\begin{tabular}{|l|c|c|c|c|c|}
\hline \multirow{2}{*}{$\begin{array}{l}\text { Indi- } \\
\text { cator }\end{array}$} & \begin{tabular}{c}
$\mid 4$ \\
\cline { 2 - 5 } \\
$(\mathrm{N}=36)$
\end{tabular} & $\begin{array}{c}\text { Skeletal } \\
\text { Chest CT } \\
(\mathrm{N}=32)\end{array}$ & $\begin{array}{c}\text { Pelvic CT } \\
(\mathrm{N}=34)\end{array}$ & $\begin{array}{c}\text { Brain CT } \\
(\mathrm{N}=32)\end{array}$ & $\begin{array}{c}\text { Level } \\
\mathrm{P}\end{array}$ \\
\hline $\begin{array}{l}\text { Moca- } \\
\text { test }\end{array}$ & $22.4 \pm 3.0$ & $20.6 \pm 3.2$ & $22.7 \pm 3.5$ & $23.3 \pm 2.8$ & 0.0102 \\
\hline
\end{tabular}

This cognitive decline is a result of many reasons, where in addition to neurodynamic changes as results of craniocerebral trauma, there are also psychoemotional disorders, that make difficulties for attention concentration and memorization, slowness of mental processes $[7,8]$. Besides, the worst indicators in patients with chest CT may also be due to hypoxic changes of mixed genesis, aggravating organic, and functional changes in the brain $[9,10]$.

To objectify the diagnosis of cognitive impairment, we used the method of neurophysiological assessment of evoked potential P300. Cognitive caused potentials are indicators of the endogenous bioelectric brain activity associated with learning mechanisms [11].

The results in the studying of cognitive functions show a significant change in peak latency in all studied groups $(p=0.0276)$. In that way, in the group of skeletal CT, it is at $354.3 \mathrm{~ms}$; in the group of chest CT it is at $358.3 \mathrm{~ms}$; in the group of pelvic CT, peak latency is $352.6 \mathrm{~ms}$.

Attention is drawn to the fact that the most significant increase in peak latency is observed in patients with chest combined trauma.However, the peak latency values in patients with skeletal and pelvic combined injuries are also quite high. This circumstance can be explained by the actual lengthy stay in the immobilized position, reduced mental and physical activity, and the presence of prolonged pain syndrome after injury. Also, patients with thoracic combined traumas are subject to mixed hypoxia during all stationary periods. Taking into account all results on depression rates (statistically significant presence of depression in $92 \%$ of cases with the highest scores according to Beck's scale in groups of patients with skeletal and pelvic combined traumas) this factor can also affect cognitive dysfunction $[12,13]$.

Analysis of the EEG results allowed to note statistically significant changes in the absolute factor of asymmetry in almost all leads except F7-F8 (Table 2). The lowest values were found in patients from the group of pelvic CT, where the average value of the absolute factor of asymmetry wasset at the level $-7.4(p=0.0008)$. In groups of patients with thoracic and skeletal CT an increase in the total factor of asymmetry relative to the control was observed (24.1; 22.4 and 18.8 , respectively). Thus cortical asymmetry is the most clearly seen in patients with pelvic CT. 
The comparison of the values of the absolute asymmetry factor in six leads, depending

Table 2 on the structure of trauma (medians \pm quartile range)

\begin{tabular}{|c|c|c|c|c|c|}
\hline \multirow{2}{*}{$\begin{array}{c}\text { Indicator } \\
\text { of Absolute } \\
\text { Factor of } \\
\text { Asymmetry } \\
\text { in leads }\end{array}$} & \multicolumn{4}{|c|}{ Trauma structure } & \multirow[b]{2}{*}{ Level P } \\
\hline & $\begin{array}{l}\text { Skeletal CT } \\
\quad(N=36)\end{array}$ & $\begin{array}{l}\text { Chest CT } \\
(N=32)\end{array}$ & $\begin{array}{l}\text { Pelvic CT } \\
(N=34)\end{array}$ & $\begin{array}{l}\text { Brainconcussion } \\
\qquad(N=32)\end{array}$ & \\
\hline F7-F8 & $29.8[4.1: 41.6]$ & $25.6[4.0: 45.2]$ & $-25.5[-37.0: 35.2]$ & $28.8[12.2: 39.6]$ & 0.1331 \\
\hline F3-F4 & $15.2[-2.6: 19.6]$ & $14.2[11.8: 51.0]$ & $-9.6[-17.4: 5.8]$ & $9.6[-2.1: 12.2]$ & 0.0003 \\
\hline $\mathrm{C} 3-\mathrm{C} 4$ & $6.8[-4.4: 22.3]$ & $10.2[8.1: 49.1]$ & $-30.2[-57.8: 5.2]$ & $13.5[9.9: 20.1]$ & 0.0002 \\
\hline T5-T6 & $39.0[28.4: 48.0]$ & $22.4[20.1: 55.1]$ & $-48.2[-80.9: 22.8]$ & $24.6[11.4: 43.4]$ & 0.0067 \\
\hline P3-P4 & $7.8[-2.2: 30.1]$ & $21.5[-6.9: 56.8]$ & $-21.2[-53.5: 12.4]$ & $17.2[-17.7: 26.5]$ & 0.0086 \\
\hline $\mathrm{O} 1-\mathrm{O} 2$ & $34.1[16.4: 43.3]$ & $30.1[0.1: 33.1]$ & $13.3[-64.3: 19.7]$ & $21.7[-9.7: 22.5]$ & 0.0061 \\
\hline Average & $24.1[0.1: 29.8]$ & $22.4[20.4: 34.5]$ & $-7.4[-52.2: 9.3]$ & $18.8[11.5: 23.2]$ & 0.0008 \\
\hline
\end{tabular}

The study of heart rate variability (HRV) was carried out on the second-third day and tenth - fourteenth day of stationary treatment of patients with combined traumas. During the second-third days after trauma, cardiointervalographywas registered only at the quiescent state. On the first day after injury, a significant decrease in the parasympathetic effect was observed with increased activity of the sympathetic link, which was followed by changes in the spectral analysis indices and SDNN, which represents the total effect of vegetative regulation, which values were less than $44.0 \mathrm{~ms}$, that indicates a decrease in heart variability rhythm and a decrease in adaptive capabilities of the organism (for example, in the group of skeletal combined trauma it is equal $18.7 \mathrm{~ms}$, in the group of chest combined injury $-244.8 \mathrm{~ms}$, in the group of pelvic combined trauma is $19.8 \mathrm{~ms}(p=0.0107)$ [ $14,15,16]$. The second study was carried out on the tenth-fourteenth days after the injury. The prevalence of parasympathetic regulation characterized this period. Statistically significant changes in indicators SDNN were noted (at a rate of 45.0$70.0 \mathrm{~ms}$, in a study in patients of all groups, including the control group, it was 5-8 times higher; RMSSD (an increase of $10-18$ times (at a rate of $36.30-48.55 \mathrm{~ms})(p=0,0003)$.

Spectral analysis revealed a decrease in the total power of the spectrum in the groups of pelvic combined trauma, brain concussion, but in less degree of skeletal combined trauma. The power of the frequency component $(\mathrm{HF})$ is in the normal range, but the power of the waves LF and VLF, reflecting the influence of the sympathetic link, is reduced. The permissible values of the wave spectrum were observed only in the group of patients with chest combined trauma. The importance of central structures in the acute period in patients with CT of the chest and pelvis is observed. The persistent tension of regulatory mechanisms is indicated by heart rate, characterized by tachycardia in patients of all groups. According to the value of the vegetative rhythm index, its increase by two times was noted in patients with thoracic and pelvic injuries. The stress index (TI), which characterizes the activity of the sympathetic regulation mechanisms, was 400-600 c.u. at rest (at a rate of 30-150 c.u.), also in patients with the chest and combined pelvic traumas. The results indicate an increase in sympathetic reactivity.

Heart rate variability was in the normal range (SDNN<44 ms) by the end of hospital stationary in $88.2 \%$ (90 patients) with combined trauma, the worst results were observed in the group with pelvic CT ( 5 patients with pelvic CT, 4 patients with chest CT and 3 patients with skeletal $\mathrm{CT}$ had moderate decrease in rhythm variability (SDNN 20-44 ms)).

Conclusions. A wide range of neurological disorders is formed in patients with brain concussion and skeletal and thoracic injuries, the presence of which leads to a worsening of the course of combined injuries. In the acute period, patients with combined trauma have psycho-emotional disorders of different degrees, have cognitive deficits, and vegetative dysfunction. Welltimed correction of the revealed violations can improve adaptation processes and reduce the time of the rehabilitation period.

\section{Disclosures:}

The authors declare no conflict of interest.

\section{References}

1. Aldrian S.,Wernhart S., Negrin L. Epidemiological and economic aspects of polytrauma management in Austria. Wien Klin. Wochenschr. 2012:124(3):78-84. https://doi.org/10.1007/s00508-011-0105-x

2. Styazkina S. N., Shanina S., Merzlyakova D. A. Combined injuries. Synergy of Sciences. 2018;22:1290-1293.

3. Krestan C. R., HeroldC. Polytrauma. Radiology. 2014;54(9):859-860.

https://doi.org/10.1007/s00117-013-2633-z

4. Pfeifer R., Pape H. C. Diagnostics and treatment strategies for multiple trauma patients. Chirurg. 2016;87(2):165-173. https://doi:10.1007/s00104-015-0139-0

5. Contractor A. A., Brown L. A., Weiss N. H. Relation between lifespan polytrauma typologies and post-trauma mental health. Compr. Psychiatry. 2018;80:202-213. https://doi.org/10.1016/j.comppsych.2017.10.005

6. Karpov S. M., Nazarova E. O., Azoidis I. Characteristics of the neuropsychiatric status of patients in the acute phase of combined trauma. European Journal of Neurology. 2016;23(2):727-728
7. Likhterman B. L. Neurology of Traumatic Brain Injury. Moscow. 2009.

8. Smith C. Neurotrauma. Handb. Clin. Neurol. 2017;145:115132. https://doi.org/10.1016/B978-0-12-802395-2.00008-0

9. Redwan B. Biancosino C. Nikolova K. Management of Thoracic Trauma. Zentralbl Chir. 2017;142(4):421-427. https://doi.org/10.1055/s-0043-116216

10. Beitl E. V., Banasova M., Vlcek B. Nitric oxide as an indicator for severity of injury in polytrauma. Physiol. Res. 2017;66(4):551-555.

11. Kobeissy F. H. Brain Neurotrauma: Molecular, Neuropsychological, and Rehabilitation Aspects. Boca Raton (FL): CRC Press/Taylor \& Francis. 2015

12. Larsen P., Goethgen C. B., Rasmussen S. One-year development of QOL following orthopaedicpolytrauma: a prospective observational cohort study of 53 patients. Arch. Orthop. Trauma Surg. 2016;136(11):15391546.

13. Mörsdorf P., Becker S., Holstein J. H. Quality of life after multiple trauma. Chirurg. 2014;85(3):210-214. https://doi.org/10.1007/s00104-013-2601-1 
14. Nazarova E. O., Karpov S. M., Apaguni A. E. Cliniconeurophysiological features of combined injuries in the acute period. European Journal of Neurology. 2018;25(2):624. https://doi.org/10.1111/ene.13701

15. Christophorado D. Yu., Karpov S. M. Combined maxillofacial trauma, diagnostic issues, neurophysiological aspects. Russian Dental Journal. 2011;6:23-24.
16. Eliseyeva E. V., Sharipov E. M., Gandylyan K. S., Suyunova D. D. Adaptation mechanisms in patients with craniofacial trauma. Medicinskii vestnik Severnogo Kavkaza. - Medical News of North Caucasus. 2014;9(3):217-220. https://doi.org/10.14300/mnnc.2014.09061

\title{
About authors:
}

Nazarova Evgenia Olegovna, postgraduate student of the Department of neurology, neurosurgery and medical genetics; tel.: +79034464729; e-mail: golikova.jenya@yndex.ru

Karpov Sergei Mikhailovich, MD, Professor, Head of the Department of neurology, neurosurgery and medical genetics; tel.: +79054101523; e-mail: karpov25@rambler.ru

Apaguni Arthur Eduardovich, MD, Professor, Head of the Combined Injury Department in Stavropol State Emergency Hospital; Professor of the Traumatology, Orthopedics Department; tel.: +79054161001; e-mail: artuni@yandex.ru

Karpov Alexey Sergeevich, postgraduate student of the Department of neurology, neurosurgery and medical genetics; tel.: +79286354634; e-mail: www.lexa2790@gmail.com

Krokhmal' Sergey Vyacheslavovich, postgraduate student of the Department of neurology, neurosurgery and medical genetics; tel.: +79188784994; e-mail: sergey267770@gmail.com

\section{USE OF THE MODIFIED FRANKEL SCALE IN ASSESSING VERTEBROMEDULLARY DISORDERS IN EMERGENCY SERVICE OF A MULTI-SPECIALITY HOSPITAL}

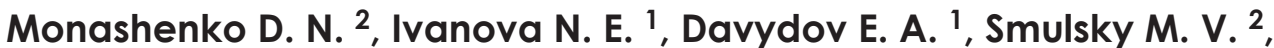 \\ Oleinik E. A. ${ }^{1}$, Ulitin A. Yu. ${ }^{1}$ \\ ${ }^{1}$ Polenov Neurosurgical Institute of Almazov National Medical Research Centre, \\ Saint-Petersburg, Russian Federation \\ 2 City Hospital № 26, Saint-Petersburg, Russian Federation
}

\section{ПРИМЕНЕНИЕ МОАИФИЦИРОВАННОЙ ШКААЫ FRANKЕL ПРИ ОЦЕНКЕ ВЕРТЕБРОМЕАУАМЯРНЫХ РАССТРОЙСТВ В УСАОВИЯХ УРГЕНТНОЙ САУЖБЫ МНОГОПРОФИАЬНОГО СТАЦИОНАРА}

\author{
А. Н. Монашенко ${ }^{2}$, Н. Е. Иванова ${ }^{1}$, Е. А. АавыАов ${ }^{1}$, М. В. Смульский ${ }^{2}$, \\ Е. А. Олейник ${ }^{1}$, А. Ю. УАитин ${ }^{1}$
1 Российский научно-исслеАовательский нейрохирургический институт им. проф. А. А. Поленова - филиал Национального меАицинского исслеловательского центра им. В. А. Алмазова, Санкт-Петербург, Российская ФеАерация
2 ГороАская больница № 26, Санкт-Петербург, Российская ФеАерация

Spinal canal deformities of various etiologies are one of the most severe types of spine pathology, which often cause disability and social alienation of patients, which requires long-term, expensive, multi-stage treatment. This indicates the high medical and social significance of the problem and requires developing a unified approach to the treatment of this pathology, in particular: choosing optimal tactics of surgical procedures to reduce the frequency of both immediate and long-term complications and return the patient to the previous level of activity. Usage of our modified Frankel scale based on the analysis of 236 cases of spinal canal deformities allows a to assess neurological disorders in patients not only with spinal injuries but also with other vertebromedullary pathologies, such as degenerative-dystrophic, inflammatory and tumoral diseases of the spine and spinal cord.

Keywords: spinal canal deformities, modified Frankel scale, vertebromedullary pathology

Деформации позвоночного канала различного генеза являются одним из самых тяжелых видов патологии позвоночника, которые часто приводят к инвалидизации и социальной дезадаптации пациентов, что требует длительного, дорогостоящего, многоэтапного лечения. Все это свидетельствует о высокой медико-социальной значимости проблемы и требует разработки единого подхода к лечению данной патологии, а именно: выбору оптимальной тактики оперативных вмешательств с целью снижения частоты развития как ближайших, так и отдаленных осложнений и возвращения пациенту прежнего уровня активности. На основании опыта применения у 236 пациентов с деформациями 